\title{
Staying Alive: Leadership in COVID-19 World
}

\author{
Carol Stewart \\ Southern Connecticut State University
}

\begin{abstract}
While this unprecedented time of COVID-19 has resulted in financial loss for many companies, it's also produced new leadership opportunities. Remote work, at-home schooling, and socially-distancing are a few examples of the new norm and new business possibilities. As crisis proverbially breeds innovation, new businesses have already sprung up around the world in support of growing demands. History shows this growth in entrepreneurial endeavors to be a trend during times of economic downturn. More than half of 2009 Fortune 500 list and just under half of 2008's Inc. list were created during a recession or bear market. Challenging economic times often seed the growth of entrepreneurial capitalism. One reason for this growth is that startup companies begun during times of high stress tend to be capable of operating in less favorable conditions. In times of economic upheaval, even mature businesses with longer history and deeper pockets require special leadership to 'pivot' their operational strategies to stay viable. This paper explores effective leadership theories to explain the success during uncertain times.
\end{abstract}

Keywords: leadership, entrepreneurship, situational leadership, pandemic, pivoting

\section{INTRODUCTION}

There is a wide variety of leadership theories offered to explain or teach the best practices within that important field. Noted leadership theories date back to the 19th century when Thomas Carlyle proposed his Great Man theory (Carlyle, 1840). His focus on inborn traits was shared by others up through the mid-20th century when research shifted toward examination of behavioral, situational, and/or relationship factors to help better explain leadership styles. As with leadership, studies of entrepreneurship have varied focus, from psychological and sociological to economic and resource-based factors. The similarities between successful leaders and entrepreneurs seems rather obvious. Having a vision and possessing effective communication, risk-taking, and problem-solving skills are frequently noted attributes of both. But do these shared characteristics or behaviors mean successful entrepreneurs are automatically successful leaders? Would effective leaders naturally be entrepreneurial experts? And why are these questions important, especially in times of relative uncertainty such as we're experiencing now with COVID-19?

Examination of leadership and entrepreneurship theories uncover one area of similarity which seems highly relevant in this current pandemic environment: The influence of contextual factors. The situation or context in which leaders and entrepreneurs make decisions strongly influences the effectiveness of those choices even in the strongest of economic times. Business success hinges on the ability to both react quickly and appropriately, and be adeptly proactive in regard to changing environmental conditions. The introduction of novel and rapidly changing circumstances, such as those brought about by the COVID-19 pandemic, has heightened uncertainty in the decision-making process for entrepreneurs and leaders alike. 
Why is it then that some people and organizations have been able to quickly adapt and even thrive under pandemic conditions while others have floundered or faced closure?

Situational and contingency leadership theories incorporate environmental factors in regard to leadership style and help explain how and why some businesses succeed in the midst of unknown and/or shifting circumstances while others do not. The element of uncertainty, inherent in entrepreneurial endeavors (Dance, n.d.) and times of economic crisis, is best addressed by those adopting a situational/contingent leadership style. Examples exist of companies large and small which have been able to successfully navigate the uncharted territory of the COVID-19 pandemic over the past year while other businesses have been forced to close. The difference? The successful organizations have people with the ability to effectively lead and decision-make within relatively high levels of uncertainty. Whether in regard to an entrepreneur in the traditional sense - e.g., launching a new business venture "on your own" - or an experienced leader in an established company, situational leadership theory offers the key to successful business operations even in times of pandemic.

\section{THEORETICAL BACKGROUND}

There is no shortage of theories concerning leadership style and what distinguishes people deemed successful leaders from the rest of the crowd. In the mid-1800's, the Great Man theory suggested inborn traits were the answer when looking for the root cause of successful leadership (Carlyle, 1840). Despite a lack of empirical validation, the Great Man theory's early premise that leaders are born, not made has demonstrated strong staying power (Halaychik, 2016). Trait theories, which share Great Man's internal focus, were popular well into the $20^{\text {th }}$ century; they claimed inborn characteristics separate successful leaders from the not-so-successful (Belyh, 2020). Common examples of these natural-born leaders include Alexander the Great, Napoleon, Lincoln, and Gandhi. Although there's consensus that effective leaders do share certain characteristics, evidence of these particular traits alone has not been found to guarantee leadership success (Judge, Piccolo, \& Kosalka, 2009).

In the early $20^{\text {th }}$ century, Kurt Lewin introduced a theory of leadership based on behavior (Lewin, Lippit, \& White, 1939). Lewin proposed that leadership style followed one of three behavioral patterns: Authoritarian/autocratic, participative/democratic, or delegative/laissez-faire. Each style reflects different specific behaviors of leaders in regard to how they lead. Behavioral theories gained popularity in the mid1900 's with the notion that leadership is not necessarily inborn but can be learned, and that people can be trained to develop successful leadership behaviors (Mulholland, 2019). As with trait theories, behavioral theories proved useful but were limited in practice as they didn't address the effect of leaders' individual personality and experience, or of the particular situational circumstances involved ("Behavioral Theories," 2013).

To address the limitations of inborn characteristics and behavioral theories, a number of new leadership analyses were introduced in the mid- $20^{\text {th }}$ century that included contextual factors in the analysis of leadership style. Fred Fielder's Contingency Model was among the first. It proposed that effective leadership was based on task and context factors; i.e., certain types of leaders were better in certain situations (Fiedler, 1964, 1967). The Path-Goal Theory followed with a focus on leaders' influence on followers' expectations and goals in different situations (Evans, 1974; House, 1971). Paul Hersey and Ken Blanchard's Situational Leadership Model (1977) went further to suggest effective leaders adjusted their leadership style to meet the unique needs of any given situation; i.e., successful leaders had fluid leadership style and knew how to modify their style accordingly in a variety of situations.

As with leadership theories, studies of entrepreneurship include a variety of factors with theories tending to fall into similar general groupings. Richard Cantillon was the first to coin the term "entrepreneur" in the mid 1700's (Rothbard, 1995). He and others explored the relationship between entrepreneurial activity and inborn characteristics (Nicolaou \& Shane, 2007). Other theorists looked at the behavior of entrepreneurial firms and sociological factors (Dew, Read, Saravathy, \& Wiltbank, 2008; Reynolds, 1991), while Peter Drucker introduced the idea that contextual or opportunity-based factors impact entrepreneurial success (1985). Howard Stevenson expanded on that concept by explaining how entrepreneurship included 
"the pursuit of opportunity beyond resources controlled" (Stevenson, as cited by Eisenmann, 2013, para. 2). $\mathrm{He}$ also distinguished between entrepreneurial and administrative organizational cultures. Entrepreneurial cultures focused on new opportunities often beyond the scope of current resources, while administrative cultures looked for opportunities that leveraged existing or planned resources. According to Stevenson and Gumpert (1985), "The pressures pushing companies toward either the entrepreneurial or administrative end of the spectrum with regard to the timing and duration of their commitment are a mixture of personal, organizational, and environmental forces" (para. 32).

This recognition of organizational factors impacting entrepreneurial activity highlights the sometimes very different conditions facing leaders in established organizations ("administrators") from those in startup businesses ("entrepreneurs"). When an opportunity presents itself, administrators must deal with myriad internal limitations, whether related to the existing hierarchical structure or the status of available resources, whereas entrepreneurs face external limitations from issues such as feasible fund generation or the possible involvement of others (Stevenson \& Gumpert, 1985). Situational leadership recognizes these organizational factors and acknowledges that no one style of leadership is correct in all situations. Even successful industry leaders must revise their style to address change and its related opportunities - whether technological, cultural, or pandemic in origin - or face possible failure, such as the management teams at Blockbuster, RadioShack, and EuroDisney discovered all too late (Sass, 2018). Whether an administrator or entrepreneur, how a business leader addresses opportunity and their related issues can make or break the endeavors' success.

Addressing these opportunities can be challenging in relatively 'normal' or stable socio-economic conditions. Throw in a world-wide pandemic with unprecedented socioeconomic ripple effect and many tried-and-true businesses rules are now out the window. After almost a year of organizations scrambling to react to rapid and evolving change, it's possible to look back and consider why some companies have been able to survive, why some have not been able to stay solvent, and why so many new companies have risen in response to unexpected and novel consumer needs.

\section{Surviving a Pandemic}

There are few natural threats that endanger more loss of life, economic disruption, and social disorder than large-scale disease outbreaks. The most dangerous of these threats is a pandemic. The Center for Disease Control (CDC) defines a pandemic as an "event that spreads across several countries and affects a large number of people" ("Lesson 1," 2012). Oftentimes, these exposures have a domino effect. Their financial and global economic impact can be quick and devastating while the recovery is slow and longlasting. The loss of jobs, resulting in high unemployment, impedes people's ability to engage in discretionary spending on non-essential items such as recreation, travel and entertainment. Many people receiving government assistance do not receive enough money to cover their basic living costs. There is an emotional price to pay that as well cannot be measured in dollars and cents.

As devastating as a pandemic can be, events like this can bring opportunities for those who are willing to take the risk. Business leaders see a problem (e.g., the pandemic) and use situational leadership to create solutions by pivoting their business model to survive. Entrepreneurs use situational leadership as well to create opportunities created by the pandemic to survive. Eckhardt and Shane (2003) explore how opportunities manifest in a variety of ways including "by locus of changes that generate the opportunity [where people believe they have control over the outcome of events in their lives]; the source of the opportunities themselves; and by the initiator of the change [that led to the opportunity]" (p. 334). They argue that successful entrepreneurs do not look at a shortage (or gap) not being met as the entrepreneurial opportunity but rather the cause of the shortage (or gap) as the break they were looking for.

Guillén (2020) argued that companies both large and small are dealing with the COVID-19 related pandemic reality. Many have understood the need to pivot their business model in order to survive shortterm in order to sustain and grow long-term. In other words, pivoting is necessary survival strategy where "a lateral move that creates enough value for the customer and the firm to share" (para. 2).

Dumitrasciuc and Turnea (2020) state that leading business experts set annual trends which entrepreneurs must recognize if they are to be successful. Trends provide entrepreneurs the opportunity to 
set short, medium, and long-term goals and strategies. Once this step is complete, entrepreneurs can be one step ahead of the competition. New technologies, evolving customer needs, and societal changes, including those created by financial or economic factors, provide opportunities or trends entrepreneurs are looking for. Dumitrasciuc and Turnea took this hypothesis one step further and conducted an opinion poll on trends, asking 117 participants what future trends would emerge post coronavirus pandemic. The top three trends identified were "freelancing (17\%), online entrepreneurship (17\%), and business globalization (16\%)" (p. 614).

Stangler (2009) looked at entrepreneurship from a micro level. Analyzing data from the U.S. Census, the Fortune 500, and the Inc. list of America's fastest-growing companies, he concluded: 1) Recessions and bear markets do not appear to have a significant negative impact on the formation and survival of new businesses; 2) Over half of the companies on the 2009 Fortune 500 list and just under half of the 2008 Inc. list began during a recession or bear market; and 3) Job creation from startups is much less volatile and sensitive to downturns than job creation in the entire economy (p. 3). One emerging trend Stangler noted was "each year, new firms steadily recreate the economy, generating jobs and innovations. These companies may be invisible, or they may one day grow into household names" (p. 3).

\section{Examples of Situational Leadership}

Before the pandemic, Spotify was on target for growth as a global leader in music streaming. Established in 2007 in Sweden, Spotify'sbusiness model offered subscribers the opportunity to listen to free music in exchange for listening to advertisements. This seemed like a perfect business model for people working from home who were isolated or quarantined for months. What Spotify hadn't anticipated was when the pandemic hit, advertisers cut back on paid advertising and the company had a "notable decline in daily active users" (Spanger, 2020, para. 1). Spotify had to come up with an alternate business model, or pivot, in order to survive. It found a solution in the form of podcasts; artists and users uploaded more than 150,000 podcasts in just one month. The company further expanded this idea to include exclusive podcast deals with celebrities (e.g., the Obamas) and also started to curate playlists. By the end of the Q12020, the company had 130 million premium users worldwide with total monthly active users peaking at 286 million - a growth of $31 \%$ (Spanger, 2020, para.4).

The restaurant industry was one of the hardest hit by the pandemic. Traditionally known for customers visiting and eating inside their establishments, restaurants were forced to pivot or face closing their doors. Many restaurants developed creative ways to stay open by turning to take-out, delivery, and catering services along with limited capacity eat-in dining (where and when allowed). A few restaurants went one step further and offered weekly meals delivered to consumers' doors, either precooked or with step-by-step instructions showing how to prepare the various dishes. Denny's, a multinational chain of diners, executed a multifaceted pivot by offering drive-up ordering, contactless delivery, curbside takeout, and shareable family packs. In more than 30 locations on the American west coast, Denny's launched Denny's Market where customers could also order a variety of sub- $\$ 10$ grocery items for pickup. This strategy allows Denny's to capitalize on customer loyalty where customers can purchase "supplies they need without compromising social distancing protocols...The list of items available includes staples like bacon, eggs, bread, steaks, and toilet paper" ("Denny's Market," n.d., para. 4).

Unilever is a 150 -year old company that produces $400+$ consumer products ranging from ice cream to tea to shampoo and other household products. The advantage of being a large company, or one with several subsidiaries, is it can pivot from manufacturing one product line to another. When the COVID-19 pandemic hit and it was clear that the situation wasn't going away soon, Unilever recognized a decrease in demand for beauty and personal care products and an increase in homecare cleaners and hygiene products ("Halfyear results," 2020). Pivoting its business model in order to keep employees working while offering indemand goods and generating revenue became the higher priority.

Behind each of these successes is a leadership team that understands the need (and often urgency) to pivot the organization's business model to meet unforeseen changes. 


\section{Results: When Situational Leadership Is Not Enough}

There was a time not long ago when spending a Saturday "out" meant shopping at a mall, eating dinner at a restaurant, or seeing a movie in a movie theater. One could catch a train or subway to the nearest stadium to catch a sporting event alongside thousands of other adoring fans. But COVID-19 changed all of that and it may be a long time, if ever, before we have those opportunities again. The hardest-hit industries - such as entertainment, sports, and transportation - may never be the same. These industries rely on faceto-face interaction to survive and it took only one pandemic to bring everything to a halt. Many of these companies aren't able to pivot because their infrastructure is too dependent on other factors. For example, retailers have to deal with people being afraid to shop in person and/or indoors, not to mention local- or state- mandated store lockdowns. Many stores tried to pivot to online sales with free delivery or curbside pickup but the high cost of payroll and rent was more than they could afford. Long-time retailers such as Brooks Brothers, GNC, and J.C. Penney are but a few examples of companies that haven't been able to survive in current pandemic conditions and have filed for bankruptcy (Thomas, 2020).

Also, on the endangered list are movie theaters, buffet-style restaurants, and salad bars of all kinds. Any type of serve-yourself food will take a long time to recover and when it does, expect a whole new look. Stay-at-home living, whether willing or involuntary, has ended the life of many common products and services, but it's also spurred the growth of new cottage industries. Salad bars and coffee stations may be a thing of the past, but not all hard-hit businesses are gone forever. Entrepreneurs will continue to find new opportunities such as reviving drive-in theaters, expanding streaming services for at-home viewing, and promoting family activities; e.g., playing board games, putting together puzzles, and creating home gardens. The ability to pivot and adapt to current conditions increases the likelihood of "staying alive" for entrepreneurial leaders and organizations everywhere.

\section{Discussion}

Gillén (2020) argued that not all businesses will be able to successfully pivot. He cited three conditions necessary for such lateral moves to work:

1) A pivot must align with the firm with one or more of the long-term trends created or intensified by the pandemic

2) A pivot must be a lateral extension of the firm's existing capabilities, cementing - not undermining - its strategic intent

3) Pivots must offer a sustainable path to profitability, one that preserves and enhances brand value in the minds of consumers (para. 11)

However, the timing is good for these conditions to be assimilated by organizations of all sizes. The pandemic has already caused disruption in daily work life, from that of big business to small mom-and-pop shops. COVID-19 wreaked professional and personal havoc on what we once deemed "normal" and spared no person or business in its wrath. The economic impact has been devastating for many, but it has also provided opportunities. The pandemic weeded out those businesses that were unable to pivot to remote work, social distancing, and adoption of new or enhanced technology, and it rewarded those that saw and acted on novel opportunities. Future research should continue to seek details of how successful leaders have adapted to this current pandemic to provide additional direction before the next crisis arises. 


\section{REFERENCES}

Belyh, A. (2020, July 25). Trait theory of leadership guide. Cleverism. Retrieved from https://www.cleverism.com/trait-theory-of-leadership-guide/

Carlyle, T. (1840). On Heroes, Hero-worship, and the Heroic in History (Vol. 12 of Library Edition: Thomas Carlyle's Collected Works). Chapman and Hall: London.

Centers for Disease Control and Prevention. (2012, May 18). Lesson 1: Introduction to Epidemiology. Retrieved from https://www.cdc.gov/csels/dsepd/ss1978/lesson1/section11.html

CNBC. (2020, April 29). Spotify's subscribers, usage amid coronavirus outbreak. Retrieved from https://www.cnbc.com/2020/04/29/spotify-spot-earnings-q1-2020.html

Dance, J. (n.d.). The uncertainty of entrepreneurship. Business Collective. Retrieved from https://businesscollective.com/the-uncertainty-of-entrepreneurship/index.html

Dennys. (n.d.). Denny's Market Launches Grocery Service. Retrieved from https://www.dennnys.com/corona-virus/

Dew, N., Read, S., Sarasvathy, S.D., \& Wiltbank, R. (2008). Outlines of a behavioral theory of the entrepreneurial firm. Journal of Economic Behavior \& Organization, 66(1), 37-59. ISSN $0167-$ 2681. https://doi.org/10.1016/j.jebo.2006.10.008

Drucker, P.F. (1985). Innovation and entrepreneurship: Practice and principles. New York: Harper \& Row.

Dumitrasciuc, L.F., \& Turnea, E.S. (2020). Entrepreneurship trends after the coronavirus pandemic. Ovidius University Annals, Economic Science Series, xx(1), 613-617.

Eckhardt, J.T., \& Shane, S.A. (2003). Opportunities and Entrepreneurship. Journal of Management, 29(3) 333-349.

Eisenmann, T.R. (2013, January 10). Entrepreneurship: A working definition. Harvard Business Review. Retrieved from https://hbr.org/2013/01/what-is-entrepreneurship

Emmett, R.B. (2010, December 15). Frank H. Knight on the 'Entrepreneur Function' in modern enterprise. SSRN. http://dx.doi.org/10.2139/ssrn.1698107

Evans, M.G. (1974). Extensions of a path-goal theory of motivation. Journal of Applied Psychology, 59(2), 172-178. https://doi.org/10.1037/h0036516

Fiedler, F.E. (1964). A Contingency Model of Leadership Effectiveness. Advances in Experimental Social Psychology, 1, 149-190. Academic Press Inc. https://doi.org/10.1016/S0065-2601(08)60051-9

Fiedler, F.E. (1967). A Theory of Leadership Effectiveness. New York: McGraw-Hill.

Gillén, M.F. (2020, July 7). How businesses have successfully pivoted during the pandemic. Harvard Business Review. Retrieved from https://hbr.org/2020/07/how-businesses-have-successfullypivoted-during-the-pandemic

Halaychik, C.S. (2016, April 13). Ch. 1: Leadership theories. Lessons in Library Leadership (pp. 1-56). Elsevier Ltd. Chandos Publishing: Cambridge, MA. https://doi.org/10.1016/B978-0-08-1005651.00001-7

Hersey, P., \& Blanchard, K.H. (1977). Management of organizational behavior: Utilizing human resources (3rd ed.). Englewood Cliffs, NJ: Prentice Hall. https://doi.org/10.1177/105960117700200419

House, R. (1971). A path goal theory of leader effectiveness. Administrative Science Quarterly, 16(3), 321.

Judge, T.A., Piccolo, R.F., \& Kosalka, T. (2009). The bright and dark sides of leader traits: A review and theoretical extension of the leader trait paradigm. The Leadership Quarterly, 20(6), 855-875. https://doi.org/10.1016/j.leaqua.2009.09.004

Lewin, K., Lippit, R., \& White, R.K. (1939). Patterns of aggressive behavior in experimentally created social climates. Journal of Social Psychology, 10, 271-301.

Mulholland, B. (2019, September 23). Behavioral theory of leadership: How to be a better leader. Retrieved from https://www.process.st/behavioral-theory-of-leadership/ 
Nicolaou, N., \& Shane, S. (2009). Can genetic factors influence the likelihood of engaging in entrepreneurial activity? Journal of Business Venturing, 24, 1-22. Retrieved from www.sciencedirect.com

Reynolds, P.D. (1991). Sociology and entrepreneurship: Concepts and contributions. University of Illinois at Urbana-Champaign's Academy for Entrepreneurial Leadership Historical Research Reference in Entrepreneurship. Retrieved from https://ssrn.com/abstract $=1505888$

Rothbard, M.N. (1995). An Austrian perspective on the history of economic thought: Classical economics (Vol. 2). Ludwig von Mises Institute.

Sass, J. (2018, January 28). Why do successful companies fail? Austral Group. Retrieved from http://www.theaustralgroup.com/blog/why-do-successful-companies-fail

Śledzik, K. (2013). Schumpeter's View on Innovation and Entrepreneurship. SSRN Electronic Journal. $10.2139 /$ ssrn. 2257783

Spanger, T. (2020, April 29). Spotify Gains 6 Million Paid Subscribers in Q1 as COVID-19 Disrupts Listening Patterns. Variety. Retrieved from https://variety.com/2020/digital/news/spotify-q12020-gains-6-million-subscribers-coronavirus-1234592814/

Stangler, D. (2009). The Economic Future Just Happened. Ewing Marion Kaufman Foundation. Retrieved from https/www.kauffman.org/wpcontent/uploads/2009/06/theeconomicfuturejusthappened

Stevenson, H.H., \& Gumpert, D.E. (1985, March). The Heart of Entrepreneurship. Harvard Business Review. Retrieved from https://hbr.org/1985/03/the-heart-of-entrepreneurship

technofunc. (2013, February 27). Behavioral Theories of Leadership. Retrieved from http://www.technofunc.com/index.php/leadership-skills-2/leadership theories/item/behavioraltheories-of-leadership

Thomas, L. (2020, December 26). The 10 biggest retail bankruptcies of 2020. CNBC. Retrieved from https://www.cnbc.com/2020/12/26/the-10-biggest-retail-bankruptcies-of-2020.html

Unilever. (2020, July 23). Half-year results: Performance reflects agility and resilience of the business. Retrieved from https://www.unilever.com/news/press-releases/2020/half-year-resultsperformance-reflects-agility-and-resilience-of-the-business.html 